\title{
Reply to 'Achieving sustainable and equitable fisheries requires nuanced policies not silver bullets'
}

To the Editor - Cisneros-Montemayor et al. ${ }^{1}$ criticize our argument ${ }^{2}$ that Indonesia's recent efforts at combatting illegal, unreported and unregulated (IUU) fishing can recover fish stocks without temporary reductions in domestic catches, and that this strategy can be scaled up. Here, we respond to their specific criticisms.

While it is true that our projection of benefits considers only the illegal aspect of IUU fishing in Indonesia, we argue there may be similar benefits to helping legal fishers gain the benefits of stock recoveries from policies that reduce or eliminate other components of IUU. The fact that fixing one component of IUU alone can reduce fishing mortality rates more than enough to drive stock recovery is a critical finding. The scope for benefits to legal fishers would only be larger from resolutions that also reduce other IUU challenges.

Cisneros-Montemayor et al. argue that policies aimed at addressing IUU fishing should be lenient towards small-scale fishers, and should not criminalize or further marginalize them. While we agree with this overall sentiment, their classification as small-scale should not excuse these fishers from violating rules and regulations. Many nearshore fisheries in the Philippines and Indonesia are severely degraded because of illegal fishing by small-scale fishers ${ }^{3,4}$. Thus, achieving sustainable fisheries requires this class of fishing activity, as well as its drivers, to be addressed. Two primary drivers of smallscale illegal fishing are poverty ${ }^{5}$ and increasing competition with industrial fishers ${ }^{6}$. Thus, reducing illegal industrial fishing should help to alleviate pressure on small-scale fishers and empower them to comply with regulations. In the case of Indonesia, anti-IUU policies primarily affect large foreign-owned and -made fishing vessels. While some foreign and local small-scale vessels are affected by the policies, there is no evidence to suggest that small-scale fishers are criminalized and marginalized. Nevertheless, we agree that governments in the developing world must strive to minimize local impacts from policies aimed at addressing IUU fishing, provide safety nets to affected local fishers, and improve social mobility in coastal fishing communities to provide fishers with options beyond fisheries. Proper management of local fisheries in addition to control of
IUU fishing within exclusive economic zones (EEZs) is essential. This includes proper implementation of any capacity-enhancing subsidies and pro-poor programmes to ensure that legal overfishing does not simply substitute for prior illegal overfishing.

We maintain that the global generalizability of our argument holds despite use of combined domestic and foreign illegal and unreported catches ${ }^{7}$. Our rough estimate of the global effects of solving IUU fishing can be refined as more detailed data become available at country and regional levels. Strategies for solving IUU fishing are indeed context-specific and may vary from place to place. Although there is no single measure that would solve IUU fishing worldwide, we can learn about effective interventions from countries leading the charge against IUU fishing, such as Indonesia, which have taken steps to address possible loopholes to effectively control IUU fishing. In addition to enhancing their monitoring, control, surveillance and enforcement at sea, Indonesia banned transshipment, ratified the Port State Measures Agreement, banned foreign-owned and -made vessels from fishing in their EEZ to prevent foreign companies from using locals to hide ownership, and banned foreigners from participating in the primary fisheries sector. Furthermore, Indonesia requires companies to disclose their beneficial owners $^{8}$, enabling prosecution of corporate beneficiaries of illegal fishing vessels, rather than their crew, effectively protecting the visible poor. Indonesia has also implemented numerous domestic policies aimed at improving the management of local fisheries, such as making their vessel monitoring system data public. These measures run counter to Cisneros-Montemayor et al's claim that Indonesia's policies are "simplistic". On the contrary, they provide a complex and comprehensive model for initiating reforms.

While we appreciate the points made by Cisneros-Montemayor et al., we reiterate that our conclusions are general and should be applicable anywhere: for countries experiencing high levels of illegal fishing by foreign fleets, solving this illegal fishing challenge can kick-start fishery recovery without the high costs to local, legal fishers usually associated with domestic fishery reform. This kick-start provides countries, especially those in the developing world, with more feasible opportunities to implement reforms. Contrary to Cisneros-Montemayor et al's claim, we did not ignore the contextual and capacity differences between developed and developing countries. Rather, these differences motivated our work.

Reniel B. Cabral1*, Steven D. Gaines 1 , Juan Mayorga'1,2, Michaela Clemence', John Lynham³, Sonny Koeshendrajana ${ }^{4}$, Umi Muawanah ${ }^{4}$, Duto Nugroho ${ }^{4}$, Zuzy Anna ${ }^{5}$, Mira $^{4}$, Abdul Ghofar ${ }^{6}$, Nimmi Zulbainarni ${ }^{7}$ and Christopher Costello ${ }^{1}$ ${ }^{1}$ Bren School of Environmental Science and Management, University of California, Santa Barbara, Santa Barbara, CA, USA. ${ }^{2}$ Pristine Seas, National Geographic Society, Washington DC, USA. ${ }^{3}$ Department of Economics, University of Hawaii at Manoa, Honolulu, HI, USA. ${ }^{4}$ The Agency for Research and Human Resource of Marine Affairs and Fisheries, Ministry of Marine Affairs and Fisheries, Jakarta, Indonesia. ${ }^{5}$ Fisheries and Marine Social Economic Department, Faculty of Fisheries and Marine Science, Universitas Padjadjaran, Bandung, Indonesia. ${ }^{6}$ Faculty of Fisheries and Marine Science, University of Diponegoro, Semarang, Indonesia. ${ }^{7}$ Faculty of Fisheries and Marine Science, Bogor Agricultural University, Bogor, Indonesia. *e-mail:rcabral@bren.ucsb.edu

Published online: 23 July 2018 https://doi.org/10.1038/s41559-018-0634-z

References

1. Cisneros-Montemayor, A. M. et al. Nat. Ecol. Evol. https://doi. org/10.1038/s41559-018-0633-0 (2018).

2. Cabral, R. B. et al. Nat. Ecol. Evol. 2, 650-658 (2018).

3. Muallil, R. N., Mamauag, S. S., Cabral, R. B., Celeste-Dizon, E. O. \& Aliño, P. M. Mar. Policy 44, 212-221 (2014).

4. Burke, L., Reytar, K., Spalding, M. \& Perry, A. L. Reefs at Risk Revisited in the Coral Triangle (World Resources Institute, The Nature Conservancy, WorldFish Center, International Coral Reef ActionNetwork, UNEP World Conservation Monitoring Centre and Global Coral Reef Monitoring Network, Washington DC, 2012).

5. Stobutzki, I. C., Silvestre, G. T. \& Garces, L. R. Fish. Res. 78, 109-118 (2006)

6. Belhabib, D., Koutob, V., Sall, A., Lam, V. W. \& Pauly, D. Fish. Res. 151, 1-11 (2014).

7. Agnew, D. J. et al. PLoS ONE 4, e4570 (2009).

8. Presidential Regulation No. 13/2018 - Beneficial Ownership (Republic of Indonesia, 2018); http://eiti.ekon.go.id/en/perpres-13-2018/

\section{Acknowledgements}

We acknowledge financial support from the David and Lucile Packard Foundation and Waitt Foundation.

Competing interests

The authors declare no competing interests. 